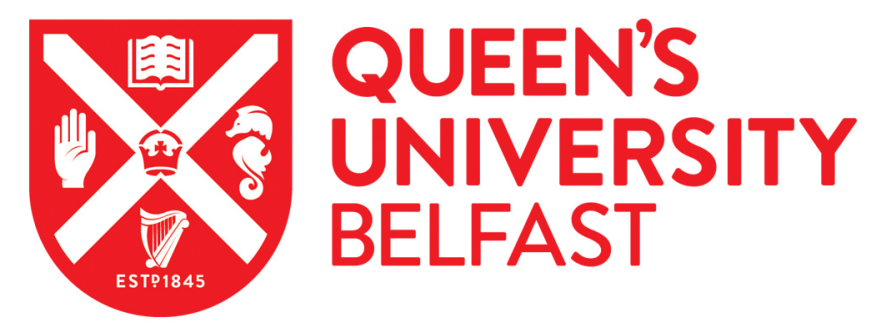

\title{
In situ sampling and speciation method for measuring dissolved phosphite at ultratrace concentrations in the natural environment
}

Han, C., Williams, P. N., Ren, J., Wang, Z., Fang, X., Xu, D., Xie, X., Geng, J., Ma, L. Q., \& Luo, J. (2018). In situ sampling and speciation method for measuring dissolved phosphite at ultratrace concentrations in the natural environment. Water Research, 137, 281-289. https://doi.org/10.1016/j.watres.2018.03.031

Published in:

Water Research

Document Version:

Peer reviewed version

Queen's University Belfast - Research Portal:

Link to publication record in Queen's University Belfast Research Portal

Publisher rights

Copyright 2018 Elsevier.

This manuscript is distributed under a Creative Commons Attribution-NonCommercial-NoDerivs License

(https://creativecommons.org/licenses/by-nc-nd/4.0/), which permits distribution and reproduction for non-commercial purposes, provided the author and source are cited.

\section{General rights}

Copyright for the publications made accessible via the Queen's University Belfast Research Portal is retained by the author(s) and / or other copyright owners and it is a condition of accessing these publications that users recognise and abide by the legal requirements associated with these rights.

Take down policy

The Research Portal is Queen's institutional repository that provides access to Queen's research output. Every effort has been made to ensure that content in the Research Portal does not infringe any person's rights, or applicable UK laws. If you discover content in the Research Portal that you believe breaches copyright or violates any law, please contact openaccess@qub.ac.uk. 
1 In situ sampling and speciation method for the measurement of

2 dissolved phosphite at ultratrace concentrations in the natural

3 environment.

4 Chao Han ${ }^{1}$, Jinghua Ren ${ }^{2}$, Paul N. Williams ${ }^{3}$, Zhaode Wang ${ }^{1}$, Xu Fang ${ }^{4}$, Di Xu ${ }^{1}$,

5 Xianchuan $\mathrm{Xie}^{4}$, Jun Luo ${ }^{4 *}$

6 ' ${ }^{1}$ State Key Laboratory of Lake Science and Environment, Nanjing Institute of 7 Geography and Limnology, Chinese Academy of Sciences, Nanjing 210008, China.

$9{ }^{2}$ Geological survey of Jiangsu Province, Nanjing 210018, China.

${ }^{3}$ Institute for Global Food Security, School of Biological Sciences, Queen's University Belfast, Belfast BT9 7BL, United Kingdom.

${ }^{4}$ State Key Laboratory of Pollution Control and Resource Reuse, School of the Environment, Nanjing University, Nanjing 210093, China.

\section{Graphic Abstract}

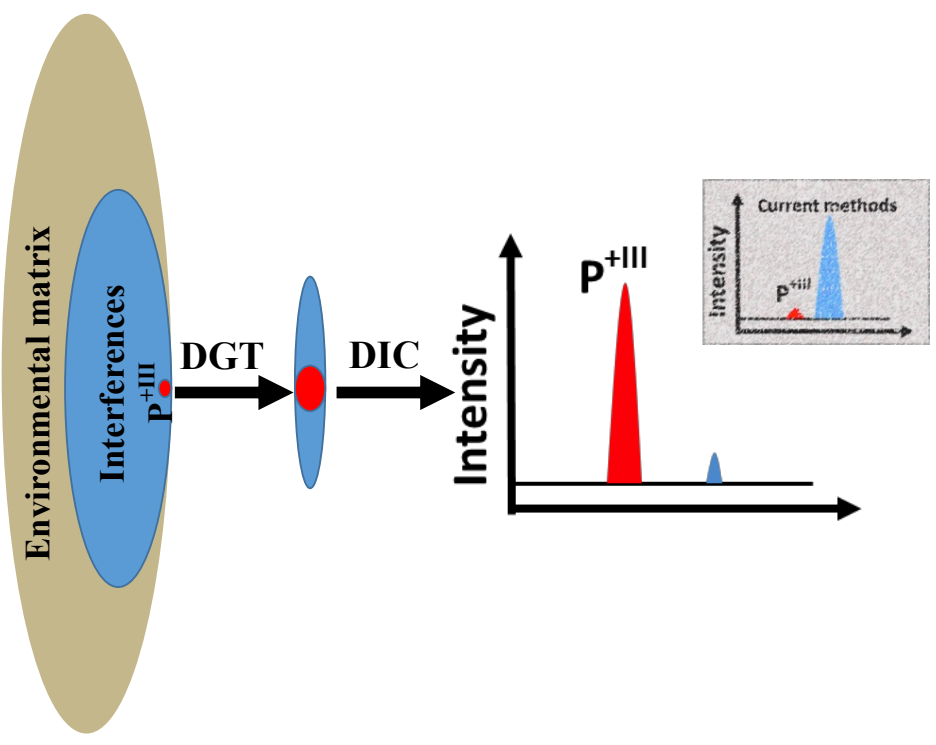


Abstract: Phosphite $\left(\mathrm{P}^{+\mathrm{III}}\right)$ is of emerging chemical interest as it's importance within the global phosphorus cycle becomes more established. Yet, to date, precise/accurate measurements of $\mathrm{P}^{+\mathrm{III}}$ in the environment are still lacking due to the inherent analytical challenges linked to its instability/ease of oxidation and ultra-trace concentration in many natural systems. Here, we present the first in-situ sampling and speciation analysis method, for dissolved $\mathrm{P}^{+\mathrm{III}}$ for terrestrial/aquatic media relevant concentrations, using the diffusive-gradient-in-thin-films (DGT) technique, combined with capillary column configured dual ion-chromatography (DIC) for enhanced-sensitivity $\mathrm{P}^{+\mathrm{III}}$ determination. Method optimization of the DGT elution regime, to simultaneously maximize desorption efficiency and DIC sensitivity, along with the characterization of diffusion coefficients (D) for $\mathrm{P}^{+\mathrm{III}}$ in agarose cross-linked (APA) polyacrylamide hydrogel, were undertaken prior to full method validation. Laboratory performance testing confirmed DGT-P ${ }^{+I I I}$ acquisition to be independent of $\mathrm{pH}(3.0-10)$ and ionic strength $(0-500 \mathrm{mM} \mathrm{NaCl})$. The effective capacity for $\mathrm{P}^{+\mathrm{III}}$ was $45.8 \mu \mathrm{g} \mathrm{cm}^{-2}$, while neither $\mathrm{P}^{+\mathrm{V}}$ (up to $10 \mathrm{mg} \mathrm{L}^{-1}$ ) or $\mathrm{As}^{+\mathrm{V}}$ (up to $1 \mathrm{mg} \mathrm{L}^{-1}$ ) impacted the quantitative measurement of DGT-P ${ }^{+ \text {III }}$. This novel DGT-DIC method's functionality stems from the herein confirmed speciation preservation provided by the DGT, combined with the double online-preseparation and -preconcentration of $\mathrm{P}^{+\mathrm{III}}$ gained by DGT and DIC being used in tandem, resulting in quantification limits as low as $7.44 \mathrm{ng} \mathrm{L}^{-1}$ for a 3-day deployment, even in complex matrixes. Field-testing of the system demonstrated the potential of this method as a geochemical exploration tool for dissolved $\mathrm{P}^{+\mathrm{III}}$ in soils/aqueous environments. 
Phosphorus (P) availability, determines productivity in the majority of global ecosystems, ${ }^{1}$ but due to the many different inorganic and organic species in various $\mathrm{P}$ oxidation states $\left(\mathrm{P}^{+\mathrm{V}}, \mathrm{P}^{+\mathrm{HII}}, \mathrm{P}^{+\mathrm{I}}, \mathrm{P}^{0}, \mathrm{P}^{-\mathrm{III}}\right)$ that exist in the environment it's characterization is complex. ${ }^{2,3}$ The long-held understanding of $\mathrm{P}$ biogeochemical processes is biased. Up until relatively recently inorganic $\mathrm{P}$ has been almost exclusively assumed to exist in the $+\mathrm{V}$ state in all but the most obscure of natural systems. Meanwhile, the redox reactions involved in (partially)-reduced P compounds [e.g., phosphite $\left(\mathrm{P}^{+\mathrm{III}}\right)$, hypophosphite $\left(\mathrm{P}^{+\mathrm{I}}\right)$, phosphine $\left.\left(\mathrm{P}^{\mathrm{III}}\right)\right]$ have largely been overlooked. However, recent evidence, arising from the discovery of these reduced-P species in a much wider range of settings, ${ }^{1,4}$ previously thought possible, coupled with the practically ubiquitous ability of microbiota to use reduced $\mathrm{P}$ compounds as their sole P source, ${ }^{5,6}$ has led to some questioning of this prevailing consensus. Attention is also being directed at the sampling and analytical methods, with there being an increasing demand for new measurement data, that better reflects the relevant concentrations/bioavailability of terrestrial/aquatic media ${ }^{1,7}$ to calibrate thermodynamic and kinetic models for risk prediction of $\mathrm{P}$ speciation and fate in the environment.

Of these reduced $\mathrm{P}$ species, $\mathrm{P}^{+I I I}$ is of particular concern within the $\mathrm{P}$ redox-cycle. Pasek and co-workers $(2008,2015)$ have commented on the P geochemistry of the early earth, stating that it was controlled by $\mathrm{P}^{+\mathrm{III}}$ and $\mathrm{P}^{+\mathrm{I}}$, which were much more soluble and reactive than the orthophosphates originally credited with this major role in early earth formation. ${ }^{2,8}$ Thus, $\mathrm{P}^{+I I I}$ and $\mathrm{P}^{+I}$ are highly relevant to the origin and development of early life. $^{2}$ Whether today, $\mathrm{P}^{\mathrm{HIII}}$ is considered as a nutrient or contaminant is a moot point. Recent microbiological/biochemical evidence suggests $\mathrm{P}^{+\mathrm{HII}}$ can play a major role in a number of key metabolic processes, which raises interesting questions regarding the nutritional value of $\mathrm{P}^{+\mathrm{III}}$ in the environment. Several studies have also reported that $\mathrm{P}^{+\mathrm{III}}$ can be directly or indirectly utilized by plants, ${ }^{9,10}$ microbes, ${ }^{5,11}$ and algae. ${ }^{12}$ However, its toxicity that $\mathrm{P}^{+\mathrm{HII}}$ is most recognized

\begin{tabular}{|l|}
\hline Paul Williams 14/4/2017 08:49 \\
\hline Deleted: ng \\
\hline Paul Williams 14/4/2017 08:49 \\
\hline Deleted: or \\
\hline
\end{tabular}


for, and this is the primary concern for environmental monitoring programmes.

Some $\mathrm{P}^{+\mathrm{III}}$ species are formed naturally, catalyzed by both abiotic ${ }^{3,13,14}$ and biological processes, ${ }^{15,16}$ while new synthesis pathways continue to be discovered. Anthropogenic sources of $\mathrm{P}^{+\mathrm{III}}$ into the environment, are poorly characterized, but are also potentially important, given the range of products that feature $\mathrm{P}^{+\mathrm{III}}$, such as $\mathrm{P}$ fertilizers, plastic stabilizers, water treatment agents, and organophosphorous pesticides. ${ }^{15,17}$ Therefore, the potential for environment enrichment and alteration of the P-cycle is significant. However, our knowledge on the behavior of $\mathrm{P}^{+\mathrm{III}}$ and its implication for biogeochemical processes is restricted to the paucity of data on its presence and cycling in the environment.

An essential prerequisite for making progress in this field is the means to precisely quantify local distributions and variations of $\mathrm{P}^{+\mathrm{III}}$ in the environment. Precise measurement of trace $\mathrm{P}^{+\mathrm{III}}$ (a few sub- $\mu$ mol or less) in natural samples is an ongoing challenge because it requires the use of very clean procedures and selective and sensitive methods. Currently procedures available for $\mathrm{P}^{+\mathrm{III}}$ analysis are based on ex-situ sampling and laboratory speciation analysis (e.g., ion-chromatography, ${ }^{18,19}$ and nuclear magnetic resonance spectroscopy ${ }^{13}$ ), which can easily change the media's properties (such as bioactivity, $\mathrm{pH}$, redox potential, metal hydroxides, etc.) and thereby make the measurements more susceptible to analytical errors during sample handling and preparation. ${ }^{20}$ Consequently, the miscalculation of $\mathrm{P}^{+\mathrm{III}}$ in the original sample restricts the scope of the environmental research on $\mathrm{P}$ species and the assessment of $\mathrm{P}^{+\mathrm{III}}$ in the ecosystem due to the destructive character of conventional methods.

A solution is to use the well-established passive sampler technique of diffusive gradients in thin films (DGT). ${ }^{21,22}$ In brief, DGT is used to measure the time-weighted average flux or concentration of chemical species (e.g., P, As, and metals) through a well-defined diffusion layer. ${ }^{23}$ A DGT device consists of a binding gel layer, which is overlaid by a diffusive hydrogel and a protective filter membrane. ${ }^{24,25}$ The analyte species of interest diffuse through the sampler, a process that acts to separate and 
clean-up the sample matrix, and are subsequently trapped and concentrated on a resin layer. $^{26}$ The technique possesses specific advantages, including the low disturbance of the target media during deployment/sample collection and low effective detection limits for trace chemicals. ${ }^{27,28}$ This technique is already being used to measure dissolved inorganic $\mathrm{P}^{+\mathrm{V}}, \mathrm{As}^{+\mathrm{III}}$, and $\mathrm{Sb}^{+\mathrm{III}}$ in various environments. ${ }^{28-31}$ Considering their structural and chemical similarities to $\mathrm{P}^{+\mathrm{III}}, 32,33$ it is reasonable to assume that the DGT method maybe a potential candidate for in-situ $\mathrm{P}^{+\mathrm{III}}$ determination. To the best of our knowledge, DGT has not yet been applied to $\mathrm{P}$ speciation measurements and the diffusion coefficient for $\mathrm{P}^{+\mathrm{III}}$ in polyacrylamide gels is unknown. Furthermore, capillary column configured dual ion-chromatography (DIC) is a robust and sensitive analytical method, which can provide enhanced-sensitivity for $\mathrm{P}^{+\mathrm{III}}$ determination. ${ }^{19,34}$ More importantly, a much lower instrumental limit of detection is established at 0.2 $\mu \mathrm{g} \mathrm{L}^{-1}$ of $\mathrm{P}^{+\mathrm{III}}$ using DIC in normal mode operation with an injection volume as low as $10 \mu \mathrm{L}$, which can perfectly accommodate the DGT method. This paper presents the first DGT-based method coupled with DIC for the in situ determination of environmentally-relevant levels of $\mathrm{P}^{+\mathrm{III}}$ in the environment. A series of validation experiments were systematically carried out to validate the performance of the new method.

\section{Experimental Section}

Materials and Chemicals. All plastic apparatus used for experiments were acid-cleaned in $10 \%(\mathrm{v} / \mathrm{v})$ hydrochloric acid $(\mathrm{HCl})$ overnight and subsequently rinsed three times in Milli-Q water $(18.2 \mathrm{M} \Omega \mathrm{cm})$ prior to use. Chemicals of analytical grade or better were purchased from Sigma-Aldrich (USA). Ionic strength was adjusted using sodium chloride $(\mathrm{NaCl})$, while the $\mathrm{pH}$ was adjusted by adding $0.1 \mathrm{M} \mathrm{HCl}$ or 0.1 $\mathrm{M}$ sodium hydroxide $(\mathrm{NaOH})$ and letting the solution equilibrate several times. A typical piston-DGT assembly employing a protective filter membrane (HVLP00010, Millipore), a diffusion layer (APA), and a precipitated zirconia-based binding gels (PZ) was prepared according to reported procedures. ${ }^{28}$ DGT-assemblies should be 
deoxygenated with nitrogen for at least $16 \mathrm{~h}$ and stored in containers filled with deoxygenated $0.01 \mathrm{M} \mathrm{NaCl}$ solution before use.

Analytical Method, Quality Assurance and DGT-concentration Calculations. A dual ion-chromatography module (ICS 5000, Thermo Fisher, USA) configured with capillary columns, was chosen for $\mathrm{P}^{+\mathrm{III}}$ measurements. Detailed instrumental conditions are given in Table S1. Procedural blanks, matrix spike i.e. $\mathrm{P}^{+\mathrm{III}}$ standards spiked into waters, elutions, wastewater, etc., and sample triplicates were used for quality assurance purposes of the coupled capillary system with acceptable recoveries ranging between $90 \%$ and $115 \%$. To alleviate/mimimise any potential background-signal effects, accumulated masses measured on the binding gels exposed to $\mathrm{P}^{+\mathrm{III}}$ were blank corrected by subtracting the procedural blank results measured on the blank binding gels that had not been exposed to solutions/matrices. The DGT-measured concentration $\left(\mathrm{C}_{\mathrm{DGT}}\right)$ can be determined by the standard DGT equation using the diffusion coefficients (D) measured in this study (see Supporting Information S1).

Diffusion Coefficient Measurement. The diffusion coefficient $\left(D, \mathrm{~cm}^{2} \mathrm{~s}^{-1}\right)$ is necessary for calculation of the DGT concentration of target analyte. Since $D$ values for $\mathrm{P}^{+\mathrm{III}}$ diffusion through the polyacrylamide gel have not been previously reported, they were determined using both a previously described diffusion cell $\left(D_{\text {cell }}\right)^{35}$ and DGT device $\left(D_{D G T}\right)$ method. $^{26}$ (see Supporting Information S2).

Batch Sorption and Elution Experiments. The set gels were cut into discs of $2.5 \mathrm{~cm}$ diameter. The binding kinetics of $\mathrm{P}^{+\mathrm{III}}$ to the resin layer was investigated by deploying the PZ-gel discs in $20 \mathrm{~mL}$ of solution at $\mathrm{pH} 7.0 \pm 0.2$ containing $100 \mu \mathrm{mol}$ $\mathrm{L}^{-1} \mathrm{P}^{+\mathrm{III}}$ in $0.03 \mathrm{M} \mathrm{NaCl}$ for $2-120 \mathrm{~min}$. The solutions were immediately shaken on a horizontal shaker during the fixed time deployment. Then, $100 \mu \mathrm{L}$ of each solution was sampled at known time intervals for DIC analysis, and the differences between the measured and initial concentration of $\mathrm{P}^{+\mathrm{III}}$ were used to determine the mass of $\mathrm{P}^{+\mathrm{III}}$ uptake by the resin.

To optimize the elution procedure the resin layer, with $2.5 \mathrm{~cm}$-diameter, was immersed into $10 \mathrm{~mL}$ of $\mathrm{P}^{+\mathrm{III}}$ solution containing $10 \mu \mathrm{mol} \mathrm{L}^{-1} \mathrm{P}^{+\mathrm{III}}$ and $0.03 \mathrm{~mol} \mathrm{~L}^{-1}$

\begin{tabular}{l} 
Paul Williams 14/4/2017 09:12 \\
Deleted: the \\
Paul Williams 14/4/2017 09:06 \\
\hline Deleted: ion-chromatography \\
Paul Williams 14/4/2017 09:07 \\
\hline Deleted: system \\
\hline Paul Williams 14/4/2017 09:13 \\
\hline Deleted: largely \\
\hline
\end{tabular}

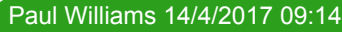

Deleted: s

Paul Williams 14/4/2017 09:14

Deleted: are

Paul Williams 14/4/2017 09:14

Deleted: the

Paul Williams 14/4/2017 09:15

Deleted: s 
$\mathrm{NaCl}(\mathrm{pH}=7.0 \pm 0.2)$ for $6 \mathrm{~h}$ and eluted by $\mathrm{NaOH}$ solutions of different concentrations from $0-1.0 \mathrm{~mol} \mathrm{~L}^{-1}$ for at least $24 \mathrm{~h}$. The elution efficiency was expressed as the ratio of the eluted mass to the mass bound in the gels.

The impact of different storage conditions on the stability of $\mathrm{P}^{+\mathrm{III}}$ adsorbed on the binding gels was also evaluated by deploying PZ-DGT assemblies (three replicates) into $20 \mathrm{~mL}$ of filtered freshwater spiked with $25 \mu \mathrm{mol} \mathrm{L}^{-1} \mathrm{P}^{+\mathrm{III}}$ for $2 \mathrm{~h}$. After DGT retrievals, the $\mathrm{P}^{+\mathrm{III}}$-loaded binding gels were gently washed with deionized water and then tracked for storage using two different procedures: 1) The PZ-gels were directly refrigerated in darkness (i.e., stored as gels) and 2) the adsorbed-P ${ }^{+I I I}$ on the gels were immediately extracted and then the elutions were refrigerated in darkness (i.e., stored as eluents). The amount of $\mathrm{P}^{+\mathrm{III}}$ recovered by selective elution with $\mathrm{NaOH}$ was immediately determined at different times during preservation.

Capacity and Interfering Effects. The capacity of PZ-DGT for $\mathrm{P}^{+\mathrm{III}}$ adsorption was determined by deploying the assemblies for $6 \mathrm{~h}$ in triplicate in $2 \mathrm{~L}$ of well-mixed solutions (at $\mathrm{pH} 7.0 \pm 0.2$ and a temperature of $\sim 22^{\circ} \mathrm{C}$ ) containing $0.03 \mathrm{M} \mathrm{NaCl}$ and $\mathrm{P}^{+\mathrm{HII}}$ of various concentrations $\left(1-500 \mu \mathrm{mol} \mathrm{L} \mathrm{L}^{-1}\right)$. To examine the effects of the PZ-DGT performance across wide $\mathrm{pH}$ and ion strength ranges, the assemblies were deployed in $2 \mathrm{~L}$ of $25 \mu \mathrm{mol} \mathrm{L} \mathrm{L}^{-1} \mathrm{P}^{+\mathrm{III}}$ solutions at varying $\mathrm{pH}$ levels $(3.0-10.0)$ or ion strengths $\left(0.0-500 \mathrm{mmol} \mathrm{L} \mathrm{L}^{-1} \mathrm{NaCl}\right)$, respectively. Besides, to test the effects of the potential competitors, i.e., $\mathrm{PO}_{4}{ }^{3}-\left(\mathrm{P}^{+\mathrm{V}}\right), \mathrm{AsO}_{3}{ }^{-}\left(\mathrm{As}^{+\mathrm{V}}\right)$ on PZ-DGT performance, the assemblies were immersed in $2 \mathrm{~L}$ of $25 \mu \mathrm{mol} \mathrm{L} \mathrm{L}^{-1} \mathrm{P}^{+\mathrm{III}}$ solutions containing additional $\mathrm{PO}_{4}{ }^{3-}\left(0.05-10 \mathrm{mg} \mathrm{P} \mathrm{L}{ }^{-1}\right), \mathrm{AsO}_{3}{ }^{-}\left(0.001-1 \mathrm{mg} \mathrm{As} \mathrm{L^{-1 }}\right)$. All testing solutions were constantly stirred at a temperature of $\sim 25^{\circ} \mathrm{C}$ and a stirring rate of $\sim 800 \mathrm{rpm} \mathrm{min}^{-1}$ during the 5-hr deployment of PZ-DGT.

DGT Applications. As already described, $\mathrm{P}^{+\mathrm{HII}}$ is heavily used for both agricultural and manufactural applications and is consequently identified in various environmental matrices. To evaluate the performance of the DGT method for $\mathrm{P}^{+\mathrm{III}}$ determination in field environments, the PZ-DGT devices combined with the DIC technique were deployed in a wide range of environmental samples (e.g. freshwater, wastewater and soils) on the basis of a literature review that established where $\mathrm{P}^{+\mathrm{III}}$ might be
Deleted:

\section{Paul Williams 14/4/2017 09:20}

Deleted: performance Paul Williams 14/4/2017 09:20

Deleted: ities 
present. ${ }^{36-38}$ Details of the sampling sites (Figure S1-S2) and protocols have been described in the Supporting Information S3. Meanwhile, $\mathrm{P}^{+\mathrm{III}}$ concentrations in those samples were determined using conventional ex-situ sampling and handling methods ${ }^{15}$ (see Supporting Information S4) for comparison.

\section{Results and Discussion}

Method Summary. In the coupling strategy, the PZ-DGT is used as a passive sampler by selectively accumulating analytes from the substrates ${ }^{28}$ while the coupled DIC is considered as the optimal quantitative method for ultratrace speciation. ${ }^{19}$ Accumulated $\mathrm{P}^{+\mathrm{III}}$ by PZ-DGT is retrieved using the optimal eluting approach. Then, the eluent is injected directly for instrumental analysis without further purification steps. For chromatographic separation, a time span of IC effluents containing target analytes and minimized interferences were roughly separated first in the analytical system (Dimension 1), and then switched to the MAX-100 capillary concentrator column in the capillary system (Dimension 2) where the analyte could achieve a further separation and detection by concentrating the analyte species and lowering detection limits.

Representative chromatograms are shown in Figure 1. The retention time of $\mathrm{P}^{+\mathrm{III}}$ (21. $1 \mathrm{~min}$ ) were verified by injecting eluent samples spiked with $\mathrm{P}^{+\mathrm{III}}$. Examples of chromatograms are available in Figure S3. Successful separation and quantification of $\mathrm{P}^{+\mathrm{III}}$ were obtained using the developed eluent gradients; however, differences can be highlighted by the peak numbers and areas in this figure. It is noted that IC seldom peaks in Dimension 1 (Figure 1-A) and a larger peak area of $\mathrm{P}^{+\mathrm{III}}$ occurs in Dimension 2 (Figure 1-B) when using the DGT method compared to those found using the traditional method, suggesting that selective in-situ preconcentration of $\mathrm{P}^{+\mathrm{III}}$ and its separation from matrices were achieved using the DGT samplers. These figures verify that PZ-DGT assemblies can be utilized in natural samples with higher sensitivity than conventional sampling methods. This feature is highly desirable for ultratrace and less stable $\mathrm{P}^{+\mathrm{III}}$ measurement. This method would work exceptionally well in complex matrices. It was also noted that $\mathrm{P}^{+\mathrm{III}}$ is not resolved from $\mathrm{CO}_{3}{ }^{2}$ 
(black line in shade area in Figure 1-A) in natural water in the analytical system owing to their similar affinities toward stationary conditions; ${ }^{39}$ however, this can be eliminated online by the configured carbonate removal device in the capillary system. $^{40}$

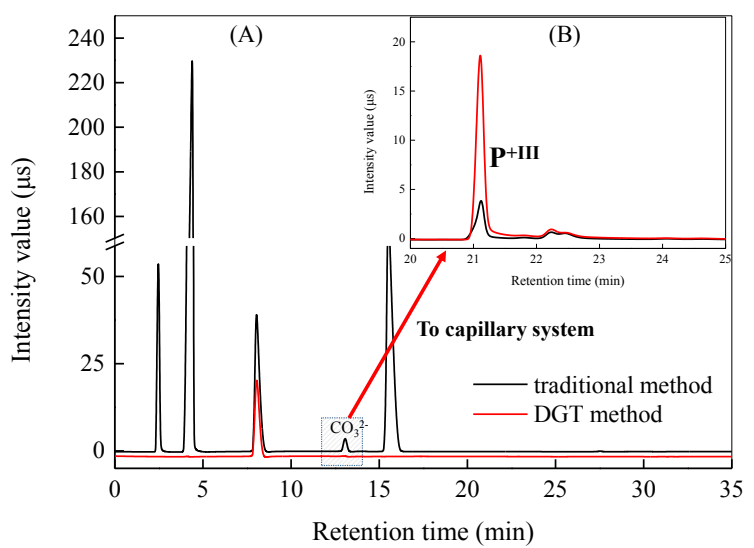

Figure 1. 2D chromatographic separations of $\mathrm{P}^{+\mathrm{III}}$ in a representative freshwater sample obtained by the traditional method (black line) and DGT method (red line). Separation of $\mathrm{P}^{+\mathrm{III}}$ in the analytical system (A) and capillary system (B). A time span of 12.0 to $14.0 \mathrm{~min}$ (shade zone) containing $\mathrm{P}^{+\mathrm{III}}$ and minimized disturbing ions was directed on-line from the analytical system to the capillary system.

Uptake and Elution Efficiencies. It was found that the $\mathrm{P}^{+\mathrm{III}}$ uptake by the PZ-gel disc increased linearly with time for the first $15 \mathrm{~min}$, followed by slow increases up to 40 $\min$ (Figure 2-A). After that, more than $99.5 \%$ of $\mathrm{P}^{+I I I}$ is absorbed by the binding gels. The average binding rate over the first $15 \mathrm{~min}$ is $18.5 \mathrm{ng} \mathrm{P} \mathrm{cm} \mathrm{min}^{-1}$, much higher than those previously reported by Sun et al. $(2014)^{30}$ of 6.13 and $11.13 \mathrm{ng} \mathrm{cm}^{-2}$ for $\mathrm{As}^{+\mathrm{V}}$ and $\mathrm{As}^{+\mathrm{III}}$ for similar binding resins. This observed sufficiently fast uptake of $\mathrm{P}^{+\mathrm{III}}$ satisfies the basis of DGT theory that the binding layers are effective zero sinks for $\mathrm{P}^{+\mathrm{III}}$, further demonstrating the potential for PZ-DGT measurement of $\mathrm{P}^{+\mathrm{III}}$.

Accurate quantification of DGT-concentrations for the target analytes relies, on their effective and reproducible elution recovery from the binding gels. ${ }^{41}$ As mentioned previously, a series of alkaline extractants such as hydroxide, bicarbonates and carbonates have already been used succesfully for eluting $\mathrm{P}^{+\mathrm{III}}, \mathrm{P}^{+\mathrm{V}}$ and other

\begin{tabular}{l} 
Paul Williams 14/4/2017 09:30 \\
\hline Deleted: d \\
\hline Paul Williams 14/4/2017 09:30 \\
\hline Deleted: tive \\
\hline Paul Williams 14/4/2017 09:32 \\
\hline Deleted: were \\
\hline Paul Williams 14/4/2017 09:31 \\
\hline Deleted: always \\
\hline
\end{tabular}


inorganic anions from the stationary phase in previous IC-based methods. ${ }^{39}$ Also, hydroxide extractants were effective in removing $\mathrm{As}^{+\mathrm{III}} / \mathrm{As}^{+\mathrm{V}}, \mathrm{Se}^{+\mathrm{IV}} / \mathrm{Se}^{+\mathrm{VI}}$ and $\mathrm{P}^{+\mathrm{V}}$ bound to Zr-oxide-based binding gels. ${ }^{28-30,42}$ In this study, eluting the PZ-gels loaded with $\mathrm{P}^{+\mathrm{III}}$ using $2 \mathrm{~mL}$ of $1.0 \mathrm{~mol} \mathrm{~L}^{-1} \mathrm{NaOH}$ for $24 \mathrm{~h}$ were first tried and then the eluent was directly injected for the DIC analysis, but a very low $\mathrm{P}^{+\mathrm{III}}$ recovery was achieved which was probably attributed to the strong signal suppression by the high $\mathrm{Na}^{+}$in the sample matrix (Figure S4-A). As suggested in Figure 1-B, the dilution of the eluent with ultrapure water can effectively avoid this matrix effect, and a complete recovery was obtained when $\mathrm{Na}^{+}$in the eluted samples were diluted to less than 50 mmol L ${ }^{-1}$. Therefore, further evaluation of the elution efficiencies using $2 \mathrm{~mL}$ of 50 mmol L ${ }^{-1} \mathrm{NaOH}$ was performed, and a consistent elution efficiency of $98.7 \%$ with good reproducibility ( $\pm 2.79 \%$ ) was obtained for the binding gels loaded with a range of $\mathrm{P}^{+ \text {III }}$ masses (Figure S4-B). These elution efficiencies were similar to those determined for other oxyanions $\left(\mathrm{P}^{+\mathrm{V}}, \mathrm{As}^{+\mathrm{III}}\right.$ and $\left.\mathrm{As}^{+\mathrm{V}}\right)$ with $1.0 \mathrm{~mol} \mathrm{~L}^{-1} \mathrm{NaOH}$ eluents. $28,30,42$ One of the major drawbacks to those eluents is the necessity of a 2.5 to 20 -fold dilution prior to the DIC analysis, which will decrease the sensitivity of trace $\mathrm{P}^{+\mathrm{III}}$ determination; ${ }^{19}$ hence, $2 \mathrm{~mL}$ of $50 \mathrm{mM} \mathrm{NaOH}$ was consequently chosen as the preferred eluent for the following experiments.

$\mathbf{P}^{+ \text {III }}$ Recovery Under Different Storage Conditions. Effective storage conditions for $\mathrm{P}^{+\mathrm{III}}$ accumulated by PZ-DGT will ultimately impair the accuracy of $\mathrm{P}^{+\mathrm{III}}$ quantification and is also a prerequisite for PZ-DGT performance. In our preliminary investigation, we found $\mathrm{P}^{+\mathrm{III}}$ recovery decreases over time and reaches $50 \%$ after a 3-day storage of the retrieved binding discs before elution at room temperature. This variation results from a partial conversion of $\mathrm{P}^{+\mathrm{III}}$ to $\mathrm{P}^{+\mathrm{V}}$ in the presence of ambient air. ${ }^{10}$ However, $\mathrm{P}^{+\mathrm{III}}$ recovery remained stable without considerable bias even after the adsorbed $\mathrm{P}^{+\mathrm{III}}$ was stored for three days as either a binding gel or eluent, as indicated in Figure 2-C. After 30 days of refrigeration, $\mathrm{P}^{+\mathrm{III}}$ recoveries of the retrieved binding gels and eluent decreased over time with a $54.8 \%$ and $78.7 \%$ retention, respectively. Thus, the refrigerated $\mathrm{P}^{+\mathrm{III}}$-contained eluent can avoid the $\mathrm{P}^{+\mathrm{HII}}$ loss more effectively for long-term stored samples. However, considering that normal DIC analysis was 

PZ-gels before elution for the sake of convenience in a routine context.
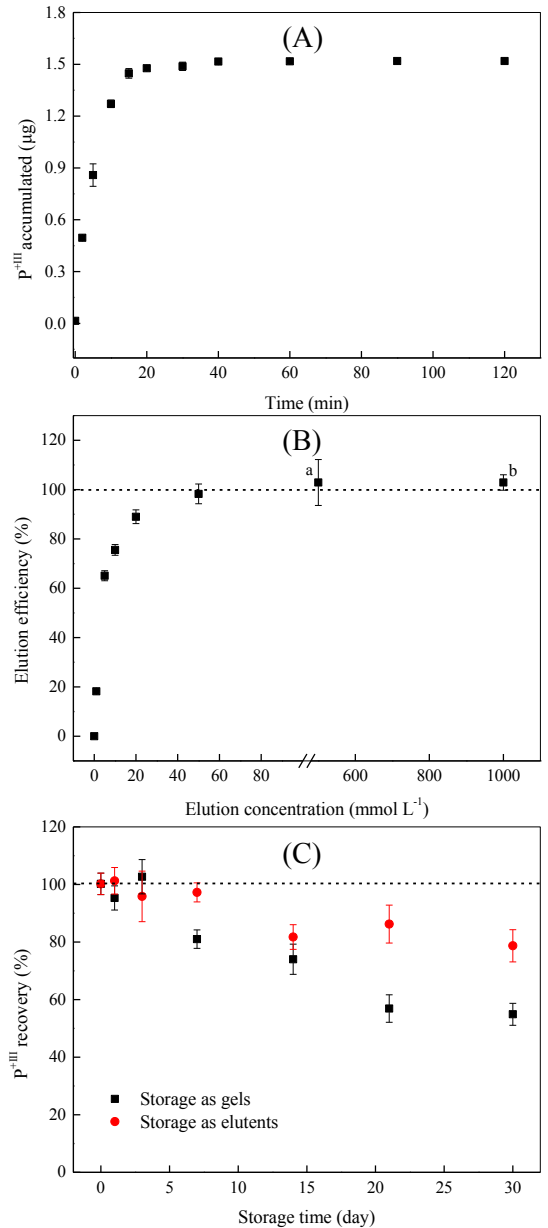

Figure 2. Kinetics of $\mathrm{P}^{+\mathrm{III}}$ bound onto the PZ-gels (A). Elution efficiencies (\%) of $\mathrm{P}^{+\mathrm{III}}$ from PZ-gels using different $\mathrm{NaOH}$ concentrations; ${ }^{a}$ and ${ }^{\mathrm{b}}$ : the eluents were diluted 10-fold and 20-fold respectively with Milli-Q water prior to DIC analysis (B). Recoveries (\%) of $\mathrm{P}^{+\mathrm{III}}$ loaded-gels which were stored as gels (•) and eluants $(\bullet)$ in a refrigerator for up to 30 days (C). All error bars represent the standard deviation (SD) of three replicates $(n=3)$.

Diffusion Coefficients. Since robust diffusion coefficients for $\mathrm{P}^{+\mathrm{III}}$ in solution are unknown, the experimental measurement of this parameter and the effect of $\mathrm{pH}$ levels and ionic strength were conducted. Detailed $D_{\text {cell }}$ measurements of $\mathrm{P}^{+\mathrm{III}}$ at different $\mathrm{pH}$ levels and ionic strengths were first investigated using the rapid diffusion cell 
method. From the data set in Table 1, we did not observe significant influences of $\mathrm{pH}$ and ionic strength, although two different $\mathrm{P}^{+\mathrm{IIII}}$ species, i.e., $\mathrm{H}_{2} \mathrm{PO}_{3}{ }^{-}$and $\mathrm{HPO}_{3}{ }^{2-}$ may exist as a function of $\mathrm{pH}$. The average $D_{\text {cell }}$ at $\mathrm{pH}$ levels ranging from 3.0 to 10 and ionic strengths ranging from $0.0 \mathrm{mmol} \mathrm{L}^{-1}$ to $-500 \mathrm{mmol} \mathrm{L}^{-1}$ was $(6.54 \pm 0.07) \times$ $10^{-6} \mathrm{~cm}^{2} \mathrm{~s}^{-1}$. This value was much higher than $D_{\text {cell }}$, for $\mathrm{P}^{+\mathrm{V}}\left(6.05 \times 10^{-6} \mathrm{~cm}^{2} \mathrm{~s}^{-1}\right)$ and $\mathrm{As}^{+\mathrm{V}}\left(6.10 \times 10^{-6} \mathrm{~cm}^{2} \mathrm{~s}^{-1}\right)$, but lower than $7.65 \times 10^{-6} \mathrm{~cm}^{2} \mathrm{~s}^{-1}$ of $\mathrm{As}^{+\mathrm{+III}}$. Meanwhile, the average $D_{D G T}$ for $\mathrm{P}^{+I I I}$ was measured as $(6.92 \pm 0.18) \times 10^{-6} \mathrm{~cm}^{2} \mathrm{~s}^{-1}$, which agreed well with $D_{\text {cell }}$ with an acceptance of less than $5.5 \%$, indicating that no measurable effect of the diffusive boundary layer between the diffusive gel and surface solution was found. ${ }^{25}$ Consistent results between $D_{\text {cell }}$ and $D_{D G T}$ have been previously reported in those studies of $D$-values for oxyanions such as $\mathrm{P}^{+\mathrm{V}}, \mathrm{As}^{+\mathrm{III}}$ and $\mathrm{As}^{+\mathrm{V}}, \mathrm{W} .{ }^{43}$

Table 1 Diffusion coefficients $\left(10^{-6} \mathrm{~cm}^{2} \mathrm{~s}^{-1}\right)$ of $\mathrm{P}^{+ \text {IIII }}$ determined using a diffusion cell $\left(D_{\text {cell }}\right)$ and DGT devices $\left(D_{D G T}\right)$ at $25^{\circ} \mathrm{C}$.

\begin{tabular}{cc}
$\boldsymbol{D}_{\text {cell }}$ & $\boldsymbol{D}_{\boldsymbol{D G T}}$ \\
\hline $6.55 \pm 0.05^{\mathrm{a}}$ & $6.94 \pm 0.24^{\mathrm{c}}$ \\
$6.53 \pm 0.11^{\mathrm{b}}$ & $6.89 \pm 0.17^{\mathrm{d}}$
\end{tabular}

${ }^{\mathrm{a}}$ and ${ }^{\mathrm{b}}$ diffusion coefficients measured in diffusive gels in synthetic freshwater at various $\mathrm{pH}$ (3.1, $4.5,6.8,8.2,9.9)$ and ionic strengths $(0,10,30,100,500 \mathrm{mM} \mathrm{NaCl})$, which were respectively calculated from Figure S5 (A-E) and Figure S6 (A-E), values are means \pm SD, $n=5$.

${ }^{c}$ and ${ }^{d}$ diffusion coefficients measured in DGT devices in synthetic freshwater containing 25 and $50 \mu \mathrm{mol} \mathrm{L} \mathrm{L}^{-1} \mathrm{P}^{+\mathrm{III}}$ at $\mathrm{pH} 6.8$ and $30 \mathrm{mM} \mathrm{NaCl}$, which were respectively calculated from Figure S7-A and $\mathbf{B}$, values are means $\pm \mathrm{SD}, \mathrm{n}=3$.

Effect of pH, Ionic Strength and Competing Ions on $\mathbf{P}^{+\mathrm{III}}$ Uptake. The influences of $\mathrm{pH}$, ionic strength and competing ions on the DGT performance are presented in Figure 3. DGT-measured $\mathrm{P}^{+\mathrm{III}}$ concentrations $\left(\mathrm{C}_{\mathrm{DGT}}\right)$ agree well with the directly-measured $\mathrm{P}^{+\mathrm{III}}$ concentrations $\left(\mathrm{C}_{\text {solution }}\right)$ in deployment solutions, with the derived ratios of $\mathrm{C}_{\mathrm{DGT}} / \mathrm{C}_{\mathrm{solution}}$ ranging from 0.95 to 1.08 with $\mathrm{pH}$ levels ranging from 3.0 to 10.0 (Figure 3-A). As a diprotic acid, $\mathrm{P}^{+\mathrm{III}}$ may speciate as $\mathrm{HPO}_{3}{ }^{2-}, \mathrm{H}_{2} \mathrm{PO}_{3}{ }^{-}$and $\mathrm{H}_{3} \mathrm{PO}_{3}$, and is often measured as total $\mathrm{P}^{+\mathrm{III}}$. $\mathrm{P}^{+\mathrm{III}}$ has a conditional $p K_{l}$ value of 1.3 and a $p K_{2}$ value of 6.7, and therefore, speciates predominantly as three species over the $\mathrm{pH}$ 
range of most natural solutions. ${ }^{20}$ It seems all species can be effectively measured by PZ-DGT, which is especially meaningful since the $\mathrm{P}^{+\mathrm{III}}$ species is highly pH-dependent.

$\mathrm{P}^{+\mathrm{III}}$ measurements by PZ-DGT also exhibit no appreciable dependency of ionic strength from 0 to $500 \mathrm{mmol} \mathrm{L}^{-1}$; with the $\mathrm{C}_{\mathrm{DGT}} / \mathrm{C}_{\text {solution }}$ values generally ranging between 0.9 and 1.1 (Figure 3-B). While the varying ionic strengths presented in environmental samples of freshwater and wastewater had ionic strengths lower than $100 \mathrm{mmol} \mathrm{L}^{-1},{ }^{44}$ seawater had ionic strengths around $500 \mathrm{mmol} \mathrm{L}^{-1}$, verifying that PZ-DGT can effectively measure $\mathrm{P}^{+\mathrm{III}}$ in a wide range of ionic strengths.

The natural presence of a relatively high concentration of anions particularly $\mathrm{P}^{+\mathrm{V}}$ and $\mathrm{As}^{+\mathrm{V}}$ was significantly analogous to the $\mathrm{P}^{+\mathrm{III}}$, which may interfere and compete with $\mathrm{P}^{+\mathrm{III}}$ for binding on PZ interaction sites. Thus, their effects on the DGT uptake of $\mathrm{P}^{+\mathrm{III}}$ were evaluated in synthetic freshwater with various combinations of anion species. Results are listed in Figure 3-C and D. There are good agreements between $\mathrm{C}_{\mathrm{DGT}}$ and the known concentrations in $\mathrm{C}_{\text {solution, }}$, as indicated by $\mathrm{C}_{\mathrm{DGT}} / \mathrm{C}_{\text {solution }}$ ratios, which were generally in a range of 0.89 to 1.12 . No appreciable effect of increasing concentration on either $\mathrm{P}^{+\mathrm{V}}$ or $\mathrm{As}^{+\mathrm{V}}$ was observed, suggesting that the binding affinity of the PZ binding resin towards $\mathrm{P}^{+\mathrm{III}}$ is strong enough to suppress the influence of the elevated levels of $\mathrm{P}^{+\mathrm{V}}$ and $\mathrm{As}^{+\mathrm{V}}$.

Accordingly, the proposed PZ-DGT method can be highly specific to $\mathrm{P}^{+\mathrm{III}}$, which is much more tolerant to $\mathrm{pH}$, ionic strength and many other potential competing anions in the natural matrices, further confirming its wide suitability for measurement of $\mathrm{P}^{+\mathrm{III}}$. Similar results were reported by Guan et al. (2015) who found that the PZ-DGT for measurements of oxyanions such as $\mathrm{P}^{+\mathrm{V}}, \mathrm{As}^{+\mathrm{V}}, \mathrm{Sb}^{+\mathrm{V}}$ etc. were very tolerant to variations of $\mathrm{pH}$, ionic strength and potential interfering ions. ${ }^{43}$ 

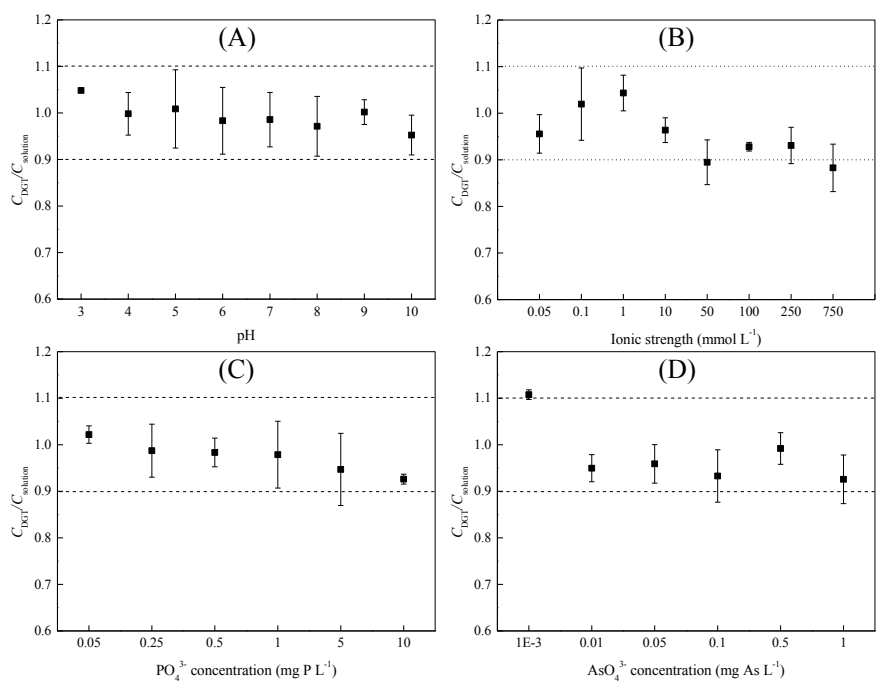

Figure 3. Effects of immersed solution $\mathrm{pH}(\mathrm{A})$, ionic strength $(\mathrm{B}), \mathrm{PO}_{4}{ }^{3-}(\mathrm{C})$ and $\mathrm{AsO}_{4}{ }^{3-}(\mathrm{D})$ on the ratio of $\mathrm{P}^{+\mathrm{III}}$ concentrations measured by DGT, C concentration in deploymet solutio, $\mathrm{C}_{\text {solution. Dotted lines indicate the } \pm 10 \% \text { accuracy }}$ zone, the accuracy requirement of the DGT analysis is satisfied. All error bars represent the $\mathrm{SD}(\mathrm{n}=3)$.

DGT Capacity. To ensure accurate calculation of analyte concentration using the DGT technique, it is essential that the adsorbent capacity is not exceeded during deployment. As Figure 4 illustrates, the experimental accumulation of $\mathrm{P}^{+\mathrm{III}}$ onto the PZ gels used in DGT measurements initially increased linearly as a function of increased solution concentration and deployment time, and deviated only slightly $(<5.0 \%)$ from theoretical accumulation. The measured capacity of PZ-DGT totalled $45.8 \mu \mathrm{g} \mathrm{cm}^{-2}$ and $46.4 \mu \mathrm{g} \mathrm{cm}^{-2}$, as judged by the significant deviations $(>39.5 \%)$ of uptake from linearity at the concentration of $2 \mathrm{mmol} \mathrm{L}^{-1}$ or deployment time of up to $128 \mathrm{~h}$. There were slight differences in the capacity values between the two sets of experiments. For such deployed natural situations with the occurring $\mathrm{P}^{+I I I}$ concentration of less than $1 \mu \mathrm{mol} \mathrm{L}{ }^{-1}$, this capacity was reached after only 231 days of deployment for $\mathrm{P}^{+\mathrm{III}}$, further confirming that PZ-DGT appears to be well suited for long-term deployment to assess natural samples far from saturation. 

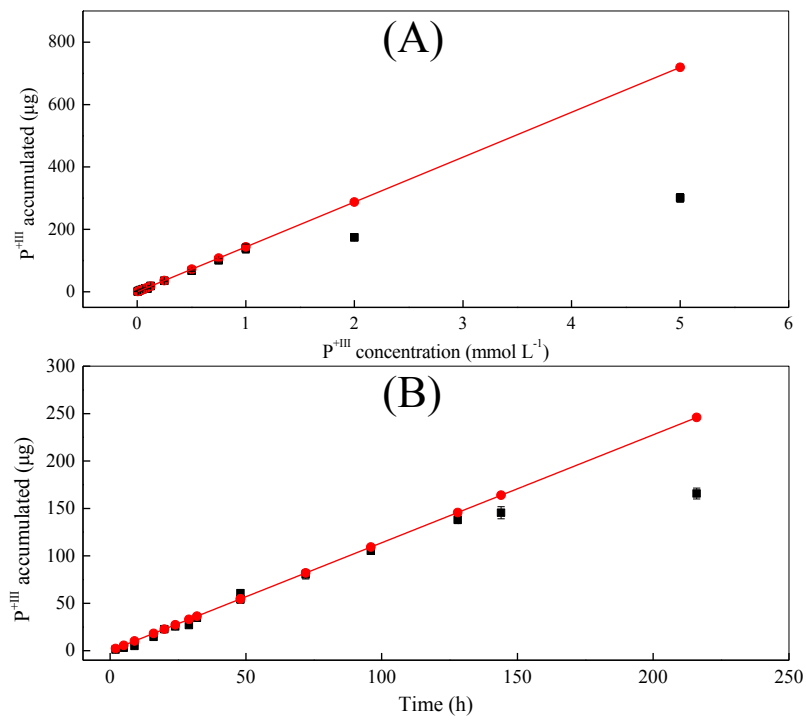

Figure 4. Accumulated masses of $\mathrm{P}^{+\mathrm{III}}$ bound onto the PZ-gels (-) within DGT devices deployed in a synthetic freshwater as a function of $\mathrm{P}^{+\mathrm{III}}$ concentrations $(0-5$ mmol L $\left.{ }^{-1}\right)(\mathrm{A})$ and deployment times $(0-216 \mathrm{~h})(\mathrm{B})$. The red solid lines represent the theoretical prediction $(\bullet)$ calculated using the eq S2 in S1. All error bars represent the $\mathrm{SD}(\mathrm{n}=3)$.

DGT Method Detection Limit. The DGT method detection limit (MDL) of $\mathrm{P}^{+\mathrm{III}}$, at the three-sigma quality level, was derived from the standard deviation of the deployment blanks (0.15 ng per device). The resulting MDL for DGT-measured $\mathrm{P}^{+\mathrm{III}}$ was $7.44 \mathrm{ng} \mathrm{L}^{-1}$ for a deployment time of $72 \mathrm{~h}$ with a typical DGT device (with a 0.80 $\mathrm{mm}$ diffusive layer and $0.13 \mathrm{~mm}$ filter layer) at $25^{\circ} \mathrm{C}$ and $\mathrm{pH}=7.0$. The $\mathrm{MDL}$ is sensitive enough for those reported sub-micromolar levels of natural $\mathrm{P}^{+ \text {III } 1,45}$ indicating that the PZ-DGT is a robust tool for trace $\mathrm{P}^{+\mathrm{III}}$ analysis. Furthermore, an enhanced sensitivity for those deployed situations with a $\mathrm{P}^{+\mathrm{III}}$ concentration lower than the MDL can be achieved by prolonging the deployment period or reducing the thickness of the applied diffusion layer. This data shows that the method described here is very suitable for ultratrace analysis of $\mathrm{P}^{+\mathrm{III}}$.

Quantitative Assessment of $\mathbf{P}^{+\mathrm{III}}$ in Samples of Environmental Interest. As a proof of principle, the present method was processed for a wide set of environmental 
Table 2 Concentrations of $\mathrm{P}^{+\mathrm{III}}\left(\mu \mathrm{g} \mathrm{\textrm {L } ^ { - 1 }}\right)$ measured in environmental samples of interest

\begin{tabular}{llcc} 
Matrix & Location & ${ }^{\mathrm{a}} \mathrm{C}_{\text {DGT }}$ & ${ }^{\mathrm{b}} \mathrm{C}_{\text {solution }}$ \\
\hline Freshwater & MeiLiang Bay & $1.10 \pm 0.15$ & $0.91 \pm 0.28$ \\
& Zushan Bay & $1.77 \pm 0.23$ & $1.02 \pm 0.36$ \\
Wastewater & Influent & $10.65 \pm 0.48$ & $7.36 \pm 1.85$ \\
& Efluent & $3.89 \pm 0.52$ & $4.29 \pm 0.72$ \\
Soil & Yixing & $140.39 \pm 0.85$ & $182.64 \pm 9.82$ \\
& Taizhou & $133.63 \pm 5.95$ & $226.26 \pm 5.33$ \\
& Suqian & $110.74 \pm 1.21$ & $217.19 \pm 20.40$ \\
\hline
\end{tabular}
probably attributed to the diverse conversion pathway of $\mathrm{P}^{+\mathrm{III}}$ (e.g. oxidation and microbial metabolism) produced in the conventional method. ${ }^{1,46}$ While, in the spiked

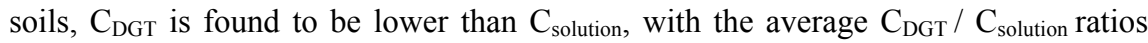
between 0.51 and 0.77 , indicating that only a small subfraction of the entire dissolved $\mathrm{P}^{+\mathrm{III}}$ fraction within the dissolved fraction is DGT-available. Indeed, the available solid $\mathrm{P}^{+\mathrm{III}}$ fraction is in dynamical equilibrium with porewater $\mathrm{P}^{+\mathrm{III}}$ and varies under different biogeochemical environments in soils. It is hypothesized that, the centrifugal extraction method invariably disturb this dynamic which can assist in measuring those $\mathrm{P}^{+\mathrm{III}}$ DGT-inert species such as complexes, colloids, etc., and hence introduce the additional measurement discrepancies. For these reasons, the labile $\mathrm{P}^{+\mathrm{III}}$ quantification by the PZ-DGT method is assumed to be preferred over the traditional extraction method as it can provide an accurate assessment of $\mathrm{P}$ availability in aqueous environments (freshwater and wastewater) and in soil. the DGT than solution. 
${ }^{\mathrm{a}} \mathrm{C}_{\mathrm{DGT}}$ and ${ }^{\mathrm{b}} \mathrm{C}_{\text {solution }}$ represent concentrations of $\mathrm{P}^{+\mathrm{III}}$ measured by the proposed method and the conventional method, ${ }^{46}$ respectively; all values are means $\pm \mathrm{SD}, \mathrm{n}=3$.

Conclusions. We developed a new approach, which combines DGT and DIC for the enhanced measurement of $\mathrm{P}^{+\mathrm{III}}$ in soils/aqueous environments. This technique has considerable benefits over currently available methods. Using a DGT method, its merits of low-disturbance sampling selectivity and preconcentration were firstly combined for the detection of redox-sensitive $\mathrm{P}$ speciation at ultratrace concentrations, This means that potential speciation changes associated with removing samples from their original states and from sample handing and analyzing are largely avoided. This is crucial when considered in the context of potential oxidation of $\mathrm{P}^{+\mathrm{III}}$ to $\mathrm{P}^{+\mathrm{V}}$ during sample processing confounding the study of P-redox chemistry and its relevant biogeochemical processes. Also, the DIC has a sensitivity and separation higher than currently available IC-based methods, ${ }^{1,18,39}$ which can further lower the limit of quantification and provide a more accurate estimation of $\mathrm{P}^{+\mathrm{III}}$. Employing the combined DGT-DIC method can effectively eliminate the need for many tedious and volume-cost pretreatments (e.g., centrifugation, filtration, and treatment with OnGuard cartridges) to reduce those $\mathrm{P}^{+\mathrm{III}}$-compromised variables (e.g., bacteria, minerals). Because of this method's satisfactory application in a wide variety of environments (i.e., $\mathrm{pH} 3.0-10$, ionic strength, $0-500 \mathrm{mM} \mathrm{NaCl}$, and less interferences from other oxyanions), it holds great potential for determining ultratrace $\mathrm{P}^{+\mathrm{III}}$ in more complicated matrices. Furthermore, PZ-DGT was originally developed for measuring various oxyanions including $\mathrm{P}^{+\mathrm{V}}$ and $\mathrm{As}^{+\mathrm{V}}$ simultaneously owing to its high capacity. ${ }^{28,43}$ Combined to a routine procedure, ${ }^{47}$ there is the possibility of using this method for simultaneously capturing the co-distributions of $\mathrm{P}^{+\mathrm{III}}$ and $\mathrm{P}^{+\mathrm{V}}$, which is particularly important in helping to elucidate the complexity of $\mathrm{P}$ speciation and biogeochemistry in soil and aqueous environments.

\section{AUTHOR INFORMATION}

\section{Supporting Information}

Paul Williams 14/4/2017 10:12

Deleted: built Paul Williams 14/4/2017 10:12 Deleted: in Paul Williams 14/4/2017 10:13

Deleted: sampler Paul Williams 14/4/2017 10:13

Deleted: non-invasion Paul Williams 14/4/2017 10:14

Deleted: s 
Supplementary text, tables and figures associated with this article can be available free of charge via the Internet at http://pubs.acs.org.

\section{Corresponding Author}

*Jun Luo Tel: (081)-025-89680632. Email: esluojun@nju.edu.cn.

**Xianchuan Xie Tel: (081)-025-86882207. Email: xchxie@nju.edu.cn.

\section{Author Contributions}

The article was written through contributions of all authors.

\section{ACKNOWLEDGMENT}

Financial support from the National Science Foundation of China (Nos. 414030972, 41203065, 21477053) and the Jiangsu Natural Science Foundation (No. BK20141060) and State Key Laboratory of Pollution Control and Resource Reuse (PCRRF16010) are gratefully acknowledged. We sincerely thank engineer Zhongbo Wei from Nanjing University, who assisted with DIC analysis.

\section{References}

(1) Morton, S. C.; Glindemann, D.; Wang, X. R.; Niu, X. J.; Edwards, M. Environmental Science \& Technology 2005, 39, 4369-4376.

(2) Pasek, M. A. Proceedings of the National Academy of Sciences of the United States of America 2008, 105, 853-858.

(3) Morton, S. C.; Edwards, M. Critical Reviews in Environmental Science and Technology 2005, 35, 333-364.

(4) Han, C.; Geng, J.; Hong, Y.; Zhang, R.; Gu, X.; Wang, X.; Gao, S.; Glindemann, D. Environmental Pollution 2011, 159, 630-635.

(5) Imazu, K.; Tanaka, S.; Kuroda, A.; Anbe, Y.; Kato, J.; Ohtake, H. Applied and Environmental Microbiology 1998, 64, 3754-3758.

(6) White, A. K.; Metcalf, W. W. In Annual Review of Microbiology, 2007, pp 379-400.

(7) Han, C.; Geng, J.; Ren, H.; Gao, S.; Xie, X.; Wang, X. Environmental Science \& Technology 2013, 47, 5679-5685.

(8) Pasek, M. A.; Sampson, J. M.; Atlas, Z. Proc. Natl. Acad. Sci. U. S. A. 2014, 111, 15468-15473.

(9) McDonald, A. E.; Grant, B. R.; Plaxton, W. C. Journal of Plant Nutrition 2001, 24, 1505-1519.

(10) Avila, F. W.; Faquin, V.; Silva, D. R. G.; Bastos, C. E. A.; Oliveira, N. P.; Soares, D. A. Ciencia E Agrotecnologia 2012, 36, 639-648.

(11) Schink, B.; Friedrich, M. Nature 2000, 406, 37-37.

(12) Zhang, J.; Geng, J. J.; Ren, H. Q.; Luo, J.; Zhang, A. Q.; Wang, X. R. Chemosphere 2011, 85, 1325-1330.

(13) Pasek, M.; Block, K. Nature Geoscience 2009, 2, 553-556. 
(14) Morton, S. C.; Zhang, Y.; Edwards, M. A. Water Research 2005, 39, 2883-2892.

(15) Han, C.; Geng, J. J.; Ren, H. Q.; Gao, S. X.; Xie, X. C.; Wang, X. R. Environmental Science \& Technology 2013, 47, 5679-5685.

(16) Tsubota, G. Soil Science and Plant Nutrition 1959, 5, 10-15.

(17) Thao, H. T. B.; Yamakawa, T. Soil Science and Plant Nutrition 2009, 55, 228-234.

(18) McDowell, M. M.; Ivey, M. M.; Lee, M. E.; Firpo, V.; Salmassi, T. M.; Khachikian, C. S.; Foster, K. L. Journal of Chromatography A 2004, 1039, 105-111.

(19) Han, C.; Geng, J.; Xie, X.; Wang, X.; Ren, H.; Gao, S. Environmental Science \& Technology 2012, 46, 10667-10674.

(20) Hanrahan, G.; Salmassi, T. M.; Khachikian, C. S.; Foster, K. L. Talanta 2005, 66, 435-444.

(21) Zhang, H.; Davison, W.; Gadi, R.; Kobayashi, T. Analytica Chimica Acta 1998, 370, 29-38.

(22) Hong, Y. S.; Rifkin, E.; Bouwer, E. J. Environmental Science \& Technology 2011, 45, 6429-6436.

(23) Davison, W.; Zhang, H. Nature 1994, 367, 546-548.

(24) Pouran, H. M.; Martin, F. L.; Zhang, H. Analytical Chemistry 2014, 86, 5906-5913.

(25) Zhou, C. Y.; Guan, D. X.; Williams, P. N.; Luo, J.; Ma, L. Q. Water Research 2016, 99, 200-208.

(26) Luo, J.; Zhang, H.; Santner, J.; Davison, W. Analytical Chemistry 2010, 82, 8903-8909.

(27) Santner, J.; Larsen, M.; Kreuzeder, A.; Glud, R. N. Analytica Chimica Acta 2015, 878, 9-42.

(28) Guan, D. X.; Williams, P. N.; Luo, J.; Zheng, J. L.; Xu, H. C.; Cai, C.; Ma, L. N. Q. Environmental Science \& Technology 2015, 49, 3653-3661.

(29) Price, H. L.; Teasdale, P. R.; Jolley, D. F. Analytica Chimica Acta 2013, 803, 56-65.

(30) Sun, Q.; Chen, J.; Zhang, H.; Ding, S. M.; Li, Z.; Williams, P. N.; Cheng, H.; Han, C.; Wu, L. H.; Zhang, C. S. Analytical Chemistry 2014, 86, 3060-3067.

(31) Lucas, A.; Rate, A.; Zhang, H.; Salmon, S. U.; Radford, N. Analytical Chemistry 2012, 84, 6994-7000.

(32) Mucci, A.; Richard, L. F.; Lucotte, M.; Guignard, C. Aquatic Geochemistry 2000, 6, 293-324.

(33) Chitrakar, R.; Makita, Y.; Hirotsu, T.; Sonoda, A. Industrial \& Engineering Chemistry Research 2012, 51, 972-977.

(34) Qiu, H.-M.; Geng, J.-J.; Han, C.; Ren, H.-Q. Chinese Journal of Analytical Chemistry 2013, 41, 1910-1913.

(35) Zhang, H.; Davison, W. Analytica Chimica Acta 1999, 398, 329-340.

(36) Qiu, H. M.; Geng, J. J.; Ren, H. Q.; Xu, Z. Y. Science of the Total Environment 2016, 543, 67-74.

(37) Yu, X. L.; Geng, J. J.; Ren, H. Q.; Chao, H.; Qiu, H. M. Environmental Science-Processes \& Impacts 2015, 17, 441-447.

(38) Avila, F. W.; Faquin, V.; Ramos, S. J.; Pinheiro, G. L.; Marques, D. J.; Lobato, A. K. D.; Neto, C. F. D.; Avila, P. R. Journal of Food Agriculture \& Environment 2012, 10, 312-317.

(39) Ivey, M. M.; Foster, K. L. Journal of Chromatography A 2005, 1098, 95-103.

(40) Ullah, S. M. R.; Adams, R. L.; Srinivasan, K.; Dasgupta, P. K. Analytical Chemistry 2004, 76, 7084-7093.

(41) Zheng, J. L.; Guan, D. X.; Luo, J.; Zhang, H.; Davison, W.; Cui, X. Y.; Wang, L. H.; Ma, L. N. Q. Analytical Chemistry 2015, 87, 801-807.

(42) Ding, S. M.; Xu, D.; Sun, Q.; Yin, H. B.; Zhang, C. S. Environmental Science \& Technology 2010, 44, 8169-8174.

(43) Guan, D. X.; Williams, P. N.; Xu, H. C.; Li, G.; Luo, J.; Ma, L. Q. Journal of Hazardous Materials 2016, 316, 69-76. 
(44) Han, C.; Yao, L.; Xu, D.; Xie, X. C.; Zhang, C. S. Scientific Reports 2016, 6.

(45) Pech, H.; Vazquez, M. G.; Van Buren, J.; Shi, L. X.; Ivey, M. M.; Salmassi, T. M.; Pasek, M. A.; Foster, K. L. Journal of Chromatographic Science 2011, 49, 573-581.

(46) Han, C.; Geng, J. J.; Xie, X. C.; Wang, X. R.; Ren, H. Q.; Gao, S. X. Environmental Science \& Technology 2012, 46, 10667-10674.

(47) Ding, S. M.; Jia, F.; Xu, D.; Sun, Q.; Zhang, L.; Fan, C. X.; Zhang, C. S. Environmental Science \& Technology 2011, 45, 9680-9686. 